\title{
17,20ß-P and cortisol are the main in vitro metabolites of 17-hydroxy- progesterone produced by spermiating testes of Micropogonias furnieri (Desmarest, 1823) (Perciformes: Sciaenidae)
}

\author{
Denise Vizziano Cantonnet ${ }^{1}$, Magdalena Mateo ${ }^{1}$, Andrés Alberro ${ }^{1}$, Florencia Barrios ${ }^{2}$ \\ and Alexis Fostier ${ }^{3}$
}

\begin{abstract}
The aim was to investigate the major C21 steroids produced by spermiating white croaker Micropogonias furnieri (Sciaenidae) in order to establish the potential mediator of gamete maturation in males of this species. The testes steroid production at the spawning season was identified incubating the ${ }^{3} \mathrm{H}-17$-hydroxy-4-pregnene-3,20-dione precursor through thin layer chromatography, high pressure liquid chromatography, enzymatic oxydation, acetylation and immunochemistry

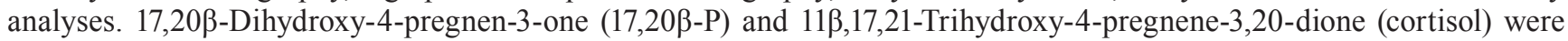
the main metabolites produced. Contrary to what we expected, 17,20ß,21-Trihydroxy-4-pregnen-3-one was not detected. Circulating levels of 17,20ß-P were undetectable in immature testes and in those at the first spermatogenesis stages, while a clear increase was observed during the whole spermatogenesis and spermiation phases (from undetectable to $1047 \mathrm{pg} \mathrm{mL}^{-1}$ ). In vitro studies together with plasma detection suggest that 17,20ß-P is a good steroid candidate involved in M. furnieri testes maturation. The role of cortisol during late phases of testes development needs further studies.
\end{abstract}

El objetivo fue investigar cuales eran los esteroides C21 más importantes producidos por los testículos en espermiación de la corvina blanca Micropogonias furnieri (Sciaenidae) para poder identificar los potenciales mediadores de la maduración gamética de los machos de esta especie. Los esteroides producidos por los testículos en espermiación fueron identificados después de su incubación con el precursor ${ }^{3} \mathrm{H}$-17-hidroxi-4-pregnene-3,20-diona a través de cromatografía de capa fina y cromatografía líquida de alta presión y posteriormente por oxidación enzimática, acetilación e inmunoquímica. Los principales

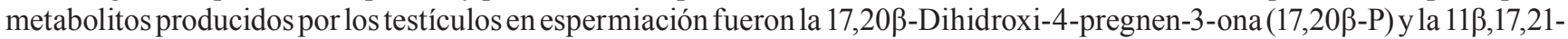
Trihidroxi-4-pregnene-3,20-diona (cortisol). Contrariamente a lo esperado, no se encontró el derivado tri-hidroxilado de la

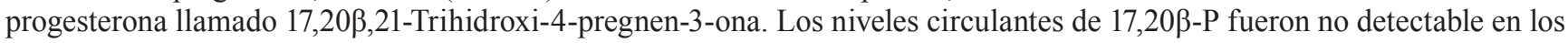
testículos inmaduros y en aquellos en inicios de espermatogénesis, mientras que un aumento claro en las concentraciones circulantes fue detectada en corvinas en plena espermatogénesis y en espermiación (desde no detectable a $1047 \mathrm{pg} \mathrm{mL} \mathrm{L}^{-1}$ ). Los resultados obtenidos in vitro junto a los cambios a nivel plasmático sugieren que la 17,20ß-P es un buen candidato a proponer como esteroide involucrado en la regulación del proceso de maduración testicular de la corvina. La función del cortisol a nivel testicular debería ser mejor estudiada en las etapas finales del desarrollo testicular de esta especie.

Keywords: Male gonad, Maturing steroids, Reproduction, Steroid synthesis, White croaker.

\section{Introduction}

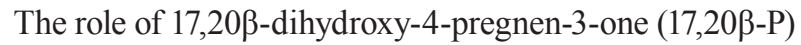
in several teleost fish has been proven as the oocytes maturation-inducing steroid (MIS) during their final development stages. This role is based on its biological effect mediated by specific receptors and its increased level during the ovulatory surge of luteinizing hormone $\mathrm{Lh}$ (Fostier et al., 1973, 1983, 1987; Scott \& Canario, 1987; Nagahama \& Yamashita, 2008). However in the past the role played by 17,20 -P in males remained unclear and critical revision articles were written regarding its activity as a maturation-inducing steroid in females (Nagahama, 1987). Moreover, the involvement of 17,20 $\beta$-P regulating different phases of teleost fish testes development has been highlighted (Schulz et al., 2010; Scott et al., 2010). The $17,20 \beta-P$ testes synthesis and release in male blood plasma has been studied in more than 100 species as per Scott et al. (2010) revision article. Salmonid is the most studied male fish model. During the reproductive cycle these fish show

${ }^{1}$ Laboratorio de Fisiología de la Reproducción y Ecología de Peces, Instituto de Biología, Facultad de Ciencias, Iguá 4225, Montevideo 11400, Uruguay. (DVC) vizziano@gmail.com (corresponding author), (MM) magdalenamateo@hotmail.com, (AA) andresalberro@gmail.com ${ }^{2}$ Sezione Istologia ed Embriologia Medica. Sapienza Università di Roma Via Antonio Scarpa 16, 00161 Roma, Italy. flor3435@hotmail.com ${ }^{3}$ INRA, UR1037, LPGP, Fish Physiology and Genomics, F35000, Rennes, France. fostier@rennes.inra.fr 
two peaks of 17,20ß-P. A small peak occurs during the progression of spermatogonial proliferation and a higher peak during the spermiating phase (Dépêche \& Sire, 1982; Baynes \& Scott, 1985; Scott \& Sumpter, 1989; Vizziano et al., 1995; Khan et al., 1997; Kusakabe et al., 2006; Schultz et al., 2010). The occurrence of a small peak of 17,20ß-P at early phases of testes development and the fact that trout

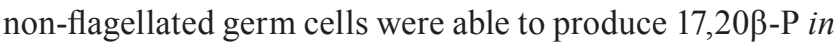
vitro when its precursor was added (Vizziano et al., 1996), suggested that early events of germ cell development could be regulated by this progestin. Indeed, 17,20 $\beta$-P has been proposed as a meiosis regulator in the Japanese eel (Miura et al., 2006) and its effect on the proliferation of early spermatogonia inzebrafish was recently demonstrated(Chen et al., 2013). Moreover, membrane progestin receptors type $\beta$ (mPR $\beta$ ) were detected in zebrafish spermatogonia and spermatocytes using immunochemistry analyses (Hanna $\&$ Zhu, 2009), while receptors type $\alpha(\mathrm{mPR} \alpha)$ were already expressed in the Micropogonias undulatus testes in a stage when only spermatogonia and spermatocytes were present (Tubbs et al., 2010). Furthermore, in Atlantic salmon and in cod the expression of the nuclear progesterone receptor (Pgr) was restricted to Sertoli cells with a strong signal in them contacting type A/early type B spermatogonia (Chen et al., 2012, 2013). In sum, in early stages of testes development germ cells are able to convert the precursors 17-Hydroxy-4-pregnene-3,20-dione or 17P into 17,20ß-P in order to regulate their proliferation and enter meiosis via progestin receptors located at the membrane of germ cells and/or in Sertoli cells.

The high increase of 17,20ß-P in salmonid during the spawning season coincides with a clear increase of Lh in plasma during spermiation (Gomez et al., 1999). Furthermore, during the complete testicular cycle, Lh or Fsh can stimulate 17,20ß-P both in vivo and in vitro, but $\mathrm{Lh}$ stimulation is greater during the late testes development phases (Le Gac \& Loir, 1988; Schulz \& Blüm, 1990; Schulz et al., 1992; Planas et al., 1993; Planas \& Swanson, 1995; Vizziano \& Le Gac, 1998). These results suggest that $17,20 \beta$-P mediates the late phases of testes development. The induction and advancement of spermiation was the clearer function suggested for this steroid (Ueda et al., 1985; Scott et al., 2010). Amplification of milt production (Baynes \& Scott, 1985; Yueh \& Chang, 1997) and stimulation of spermatozoa motility (Miura et al., 1992; Miura \& Miura, 2003; Tubbs \& Thomas, 2008) were other proposed functions.

During the spermiating season in non-salmonid male fish it was seen an increase of various progestins i.e. 17,20ß,21-Trihydroxy-4-pregnen-3-one (17,20ß,21-P), $17,20 \alpha$-Dihydroxy-4-pregnen-3-one $(17,20 \alpha \mathrm{P})$ and $17 \mathrm{P}$ in some cases reaching levels higher than 17,20ßP (Vizziano et al., 2008). These levels suggest that different progestins could be involved in gamete maturation of other fish species as well. The same condition is seen on females, where several other candidates have been proposed as maturation- inducing steroids, the evidence favouring 17,20ß,21-P as plausible alternative to 17,20ßP (Scott et al., 2010).

In the Atlantic croaker, Micropogonias undulatus (Linnaeus, 1766) males the 17,20ß,21-P affects sperm motility and velocity in vitro (Thomas, 1994). Furthermore 17,20ß,21-P plasma levels in Atlantic croaker males have been reported only in one case by Mathews et al. (2002) being undetectable during the recrudescing phase and reaching $1.01 \mathrm{ng} / \mathrm{mL}$ at the end of the sexual cycle. Our study model, the white croaker Micropogonias furnieri (Desmarest, 1823), is an important species for fisheries in Argentina, Brazil, and Uruguay. The Río de la Plata estuary and Rocha's coastal lagoons are their southern reproduction areas (Acha et al., 1999; Vizziano et al., 2002a, 2002b; Macchi et al., 2003). The steroid metabolism of the species female gonads have been previously studied reporting that during the oocyte maturation season female gonads produce both 17,20ßP and 17,20ß,21-P (García-Alonso et al., 2004). However, no data on steroid metabolism in spermiating males are available. Thus taking into account data reported about M. undulatus here we investigated if 17,20及,21-P was produced by $M$. furnieri spermiating testes. However our findings showed that the major metabolites were $17,20 \beta \mathrm{P}$ and 11ß,17,21-Trihydroxy-4-pregnene-3,20-dione or cortisol.

\section{Material and Methods}

Chemicals. Nonradioactive steroids were purchased from Sigma Chemical Co. (St. Louis, USA). $\left[1,2,6,7-{ }^{3} \mathrm{H}\right]-17-$ hydroxy-4-pregnene-3, 20-dione ( ${ }^{3} \mathrm{H}-17-\mathrm{P}$, specific activity [sp. act.] $=77 \mathrm{Ci} \mathrm{mmol-1)}$ were from Amersham-Life Sciences (U.K). ${ }^{3} \mathrm{H}-17,20 \beta$, not available commercially, was synthesised enzymatically by reduction of ${ }^{3} \mathrm{H}-17-\mathrm{P}$ with $3 \alpha, 20 \beta$-hydroxysteroid dehydrogenase Streptomyces hydrogenans (Sigma, USA) following procedures described by Vizziano et al. (1995). The names of the steroids mentioned in this paper are shown in Table 1.

Sampling. Research involving animal experimentation is in accordance with the standards for the use and care of laboratory animals in compliance with Uruguayan regulations on animal welfare (Comisión Honoraria de Experimentación Animal (CHEA)).

Sampling was carried out in the white croaker Micropogonias furnieri major spawning area during the spawning season in the Río de la Plata estuary (Acha et al., 1999; Vizziano et al., 2002a; Macchi et al., 2003). Adult males (>30 cm, Cousseau et al., 1986) were obtained from artisanal fishers of Río de la Plata coast during the spawning season. The gonad stage was determined after gentle stripping and three spermiating males were selected. The selected males were decervicated and the gonads sampled. The total weight $( \pm g)$ was recorded and the wet weight of gonads was measured $( \pm 0.1 \mathrm{~g})$ prior to maintain the gonads in cold sterile RPMI Media 1640. The gonadosomatic index was calculated using body $(M)$ and gonad $\left(M_{\mathrm{G}}\right)$ mass as: $I_{\mathrm{G}}=100 . M_{\mathrm{G}} M^{-1}$. The 
GSI of males were between 2.4 to $3.6 \%$, consistent with GSI of spermiating white croaker males (Vizziano et al., 2002b).

To verify if during the testicular cycle 17,20ß-P levels changed in the bloodstream complementary samplings were taken in an oceanographic cruise in the Río de la Plata on the spawning area and season (20-30 January); the cruise was the R/V Aldebarán (DINARA, Uruguay). During the stay in the cruise, blood of 91 croakers was collected from the caudal vessels using a heparinised syringe, maintained in ice and centrifuged for $15 \mathrm{~min}$ at $3700 \mathrm{~g}$. Plasma samples were frozen until their analysis by RIA. Fish were manipulated without anesthetic for sampling blood plasma and killed by decervication in order to sample the gonads fixed in Bouin. During the sampling the testicular stage was classified macroscopically following Vizziano et al. (2002b). The 91 males collected presented different stages of development: stage $1(n=3)$, stage $2(n=6)$, stage $3(n=12)$, stage $4(n=69)$, stage $6(n=1)$.

Table 1. Meaning of common abbreviations used in text following Kime (1995).

\begin{tabular}{|c|c|c|}
\hline Abbreviation & Full name & Other abbreviations or names \\
\hline $\mathrm{P}$ & 4-Pregnene-3,20-dione & Progesterone \\
\hline 17-P & 17-Hydroxy-4-pregnene-3,20-dione & 17-Hydroxyprogesterone \\
\hline $17,20 ß-\mathrm{P}$ & 17,20ß-Dihydroxy-4-pregnen-3-one & DHP \\
\hline $17,20 \alpha-P$ & $17,20 \alpha$-Dihyhydroxy-4-pregnen-3-one & \\
\hline 17,21-P & 17,21-Dihydroxy-4-pregnene-3,20-dione & 11-deoxycortisol \\
\hline $17,20,21-\mathrm{P}$ & 17,20ß,21-Trihydroxy-4-pregnen-3-one & $20 \beta-S$ \\
\hline cortisol & $11 \beta, 17,21$-Trihydroxy-4-pregnene-3,20-dione & Hydrocortisone \\
\hline $3 \alpha, 17 \mathrm{P}-5 \beta$ & $3 \alpha, 17 \alpha$-dihydroxy-5ß-pregnan-20-one & \\
\hline 11-deoxycorticosterone & 21-Hydroxy-4-pregnene-3,20-dione & DOC \\
\hline $11-20 ß S$ & 17,20ß,21-Trihydroxy-4-pregnen-3,11-dione & 20-dihydrocortisone \\
\hline E & 17,21-Dihydroxy-4-pregnene-3,11,20-trione & cortisone \\
\hline $11 ß-21 \mathrm{P}$ & 11ß,21-Dihydroxy-4-pregnene-3,20-dione & corticosterone \\
\hline A & 4-Androstene-3,17-dione & Androstenedione \\
\hline $\mathrm{T}$ & 17ß-Hydroxy-4-androsten-3-one & Testosterone \\
\hline $11 \mathrm{KT}$ & 17ß-hydroxy-4-androstene-3,11-dione & 11-ketotestosterone \\
\hline 11ßOH-A & 11ß-Hydroxy-4-androstene-3,17-dione & 11-betahydroxyandrostenedione \\
\hline Ad & 4-Androstene-3,11,17-trione & Adrenosterone, androstenetrione \\
\hline E2 & 1,3,5(10)-Estratriene-3,17 $\beta$-diol & $17 \beta$-estradiol \\
\hline
\end{tabular}

In vitro incubations. The testes of three males were washed twice in sterile RPMI medium 1640 (Gibco BRL, USA, 10 $\mathrm{mM}$ Hepes, $\mathrm{pH}$ 7.5) and finely chopped. Testes fragments (350 to $490 \mathrm{mg} \mathrm{mL}^{-1}$ ) were incubated with $10 \mu \mathrm{Ci}$ of ${ }^{3} \mathrm{H}-17 \mathrm{P}$ for $6-7 \mathrm{~h}$, at $22^{\circ} \mathrm{C}$. The temperature corresponds to the mean temperature during spawning season in the spawning area in the Río de la Plata (Vizziano et al., 2002a). The reaction was interrupted with ethanol at a final concentration of $80 \%$ and $10 \mu \mathrm{g}$ of unlabeled $17 \mathrm{P}$ was added. Incubates were frozen at $-20^{\circ} \mathrm{C}$ until analyzed.

Hormone identification. Testicular fragments and culture medium were homogenized with an Ultra-Turrax (T25, JanKe \& Kunkell, Germany) in ethanol/water at a final concentration of $80 / 20 \mathrm{v} / \mathrm{v}$ and steroids were extracted and analyzed as previously described (Vizziano et al., 1996). The radioactivity of the aqueous and organic phases was measured (Intertechnique, SL 4000 counter) and the organic phases were further analyzed by thin layer chromatography (TLC, 60 $\mathrm{F}^{254}$, Merck). The non-polar lipids were eliminated through three migrations in toluene/cyclohexane $50 / 50 \mathrm{v} / \mathrm{v}$ (system I). Steroid metabolites were separated in TLC (two migrations in benzene/acetone $80 / 20 \mathrm{v} / \mathrm{v}$, system II) and carriers were detected under UV light. A thin layer radiochromatogram scanner (Packard, Model 7220/21) was used to measure the radioactivity of the plates. The radioactivity peaks of the different zones of the TLC were further analyzed by reverse phase HPLC (Nucleosil, C18, $5 \mu, 4 \mathrm{~mm}, 1=250 \mathrm{~mm}$ ) after elution with dichloromethane-methanol $(90 / 10 \mathrm{v} / \mathrm{v})$ and adding internal carriers. These zones were analyzed by two different solvent systems: methanol/acetonitrile/ water 33/26/41 v/v/v (system III) and tetrahydrofuran/water $35 / 65 \mathrm{v} / \mathrm{v}$ (system IV) with a flow rate of $1 \mathrm{~mL} \mathrm{~min}^{-1}$. The elution time of internal and external standards was detected at $254 \mathrm{~nm}$ (3000 spectromonitor detector, LDC) and the radioactivity of the sample was measured with a RadioChromatography Detector (Packard, Series A-500) coupled to the HPLC. The elution times of the authentic inert steroids and the authentic radiolabeled steroids were compared. The difference between online UV absorbance and radioactivity measurements was around $0.5 \mathrm{~min}$. For further examination of the metabolites identified by TLC and HPLC a second replicate was extracted and purified by TLC (systems I and II) and HPLC (system III). After HPLC purification the 
radioactivity peaks that co-eluted with $17,20 \beta \mathrm{P}$ and cortisol as well as the polar zone that could contain the 17,20ק,21-P were extracted with dichloromethane and further analyzed as described above. The percentage of radioactivity present in each peak was calculated with the Radio-Chromatogram detector software using the radioactivity present in all peaks of the procedure as total radioactivity.

A second replicate of male 2 was extracted and analyzed without internal standards by TLC (systems I and II) and HPLC (system III) for further analysis of peaks corresponding to $17,20 \beta \mathrm{P}$, cortisol and 17,20 $3,21-\mathrm{P}$ by oxydation, acetylation and immunochemistry analyses.

Enzymatic oxidation of metabolites. After TLC and HPLC purification an enzymatic oxidation of $20 ß$ hydroxyl group of the metabolite co-eluting with 17,20ßP and of the putative area of 17,20 $3,21-\mathrm{P}$ was carried out. The radiolabeled metabolites were oxidized with $10 \mu \mathrm{L}$ of a suspension of the

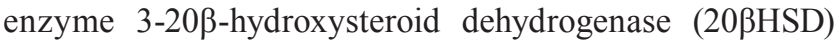
from Streptomyces hydrogenans (Sigma Co, St Louis, USA) in presence of $1 \mathrm{mM} \mathrm{NAD+}$. Incubation was carried out in a final volume of $1 \mathrm{~mL}$ of phosphate buffer $(10 \mathrm{mM}$, $\mathrm{pH}$ 7.6) at room temperature for $60 \mathrm{~min}$. The reaction was interrupted with $20 \mu \mathrm{g}$ of $17 \mathrm{P}$ and $5 \mathrm{~mL}$ of dichloromethane. The product obtained was extracted 3 times in $5 \mathrm{~mL}$ of dichloromethane and analyzed by HPLC (system III).
Acetylation. A second replicate of males 2 and 3 was extracted and analyzed by TLC (systems I and II) and HPLC for further study of the cortisol peak. Cortisol was identified by acetylation with acetic anhydride according to Mugnier (1996) and compared to a standard of cortisol acetylated together with the tritiated metabolite explored and analysed by TLC with system II.

Immunochemical identification of metabolites. The TLC 20ßS putative zone of each sample was purified by HPLC and immunochemistry analyzed after extraction of the eluate with dichloromethane. Anti-20ßS serum given by AP Scott (UK) was used at a final dilution of $1 \times 800^{-1}$. This antisera was tested by Scott \& Sorensen (1994) having less than 0.1\% of cross reactivity with several steroids tested including the 17,20P. Each extract of the 20ßS elution zone was evaporated, dried and redissolved in $100 \mu \mathrm{L}$ of phosphate buffer $(20 \mathrm{mM}$, $\mathrm{NaCl} 150 \mathrm{mM}, \mathrm{pH} 7.25)$ with $0.1 \%$ of gelatin. The incubation was carried out for $3 \mathrm{~h}$, at $4^{\circ} \mathrm{C}$ in $100 \mu \mathrm{L}$ of anti-20ßS serum. At the end of the incubation a suspension of dextran coated charcoal at $0^{\circ} \mathrm{C}(500 \mathrm{mg}$ of charcoal $+50 \mathrm{mg}$ of dextran $\mathrm{T}$ 70 in $100 \mathrm{~mL}$ of phosphate buffer) was added and samples were incubated for $12 \mathrm{~min}$ at $0^{\circ} \mathrm{C}$. Samples were centrifuged at $2000 \mathrm{~g}$ for $12 \mathrm{~min}$ and supernatants were left during 10 min to search for radioactivity. A summary of the different analyses driven for each metabolite is shown in Table 2.

Table 2. Analysis of metabolites produced by testes fragments of three males of Micropogonias furnieri at spermiating time. System I = toluene/cyclohexane $50 / 50 \mathrm{v} / \mathrm{v}$; System II= benzene/acetone $80 / 20 \mathrm{v} / \mathrm{v}$; System III = methanol/acetonitrile/water 33/26/41 v/v/v; System IV= tetrahydrofuran/water 35/65 v/v.

\begin{tabular}{|c|c|c|c|c|c|c|c|}
\hline Metabolite & System I (TLC) & System II (TLC) & System III (HPLC) & System IV (HPLC) & Enzymatic oxydation & Acetylation & Immunochemical \\
\hline 17,20ß-P & $\mathrm{X}$ & $\mathrm{X}$ & $\mathrm{X}$ & $\mathrm{X}$ & $\mathrm{X}$ & - & - \\
\hline cortisol & $\mathrm{X}$ & $\mathrm{X}$ & $\mathrm{X}$ & $\mathrm{X}$ & - & $\mathrm{X}$ & - \\
\hline 17,20,21-P & $\mathrm{X}$ & $\mathrm{X}$ & $\mathrm{X}$ & $\mathrm{X}$ & $\mathrm{X}$ & - & $\mathrm{X}$ \\
\hline $17,21-\mathrm{P}$ & $\mathrm{X}$ & $\mathrm{X}$ & $\mathrm{X}$ & $\mathrm{X}$ & - & - & - \\
\hline
\end{tabular}

Hormone measurement. 17,20 $\beta \mathrm{P}$ concentration in blood plasma was measured by RIA. Plasma was extracted using ethyl-acetate: cyclohexane 1:1 v:v. Each extract was evaporated and the dry residues were dissolved with phosphate buffer $(50 \mathrm{mM}, \mathrm{pH} 7.4, \mathrm{NaCl} 150 \mathrm{mM})$ with $0.1 \%$ of gelatin added. Incubation was carried out for $20 \mathrm{~h}$ at $18^{\circ} \mathrm{C}$ with anti17,20 -P serum (Fostier et al., 1981) at a final dilution of 1/9000. A cold suspension of dextran coated charcoal (500 $\mathrm{mg}$ of charcoal $+50 \mathrm{mg}$ of dextran $\mathrm{T} 70$ in $100 \mathrm{~mL}$ buffer phosphate) was added to the samples and incubated for 15 min at $0^{\circ} \mathrm{C}$. Then samples were centrifuged at $3500 \mathrm{~g}$ for 15 $\min$ at $2^{\circ} \mathrm{C}$ and supernatants were counted for radioactivity. The percentages of cross reactivities (CR) of each antiserum were checked and calculated in a dose which generated a $50 \%$ displacement of maximum binding of the tracer as follows: $\mathrm{CR}=100 *$ (std mass / ns mass) where std stands for the antigen and ns stands for the competitive antigen against anti-17,20 $\beta$-P (Table 3). Sensitivity was $6 \mathrm{pg} /$ tube and the coefficient of variation of the intra assay test was $20 \%$.
Table 3. Cross-reactivity of steroids with the anti$17,20 \beta-\mathrm{P}$ used for radioimmunoassay. Cross-reactivity was determined by comparing the concentrations of unlabeled cortisol and unlabeled competitors for the displacement of $50 \%$ of the antibody-bound tritiated cortisol. The full names of steroids are given shown in Table 1.

\begin{tabular}{cc}
\hline Steroids & Cross-reactivity $(\%)$ \\
\hline $17,20 ß-\mathrm{P}$ & 100 \\
$17,20,21-\mathrm{P}$ & $<0.01$ \\
$17-\mathrm{P}$ & $<0.01$ \\
$\mathrm{P}$ & $<0.01$ \\
$17,21-\mathrm{P}$ & $<0.01$ \\
Cortisol & $<0.01$ \\
$\mathrm{~T}$ & $<0.01$ \\
E2 & $<0.01$ \\
\hline
\end{tabular}




\section{Results}

Metabolism of tritiated 17-P by spermiating testes. The low radioactivity measured in the aqueous portion remaining after solvent extraction indicated a low conjugation capacity of the testes at this stage $(0.98 \%$, $1.6 \%$ and $8.5 \%$ of the total radioactivity for the three testes analysed, respectively). Regarding the unconjugated metabolites, three main peaks of radioactivity (Figs. 1a-c) could be observed in the TLC analyses of spermiating testes incubates, besides the precursor (Fig. 1d). The most polar peak (A) comigrated with highly polar metabolites. The second peak (B) corresponded to the distance of migration of cortisol using benzene/acetone 80/20 v/v. In this first analysis we were not looking for cortisol therefore it was not used as standard. In subsequent studies of C21 migration using benzene/acetone 80/20 $\mathrm{v} / \mathrm{v}$ it was clear that cortisol migrated with the system used at the area corresponding to peak $\mathrm{B}$ of radioactivity being located between the more polar 17,20,21-P (see Fig. 1, male 2, standard 2) and the less polar 17,20 $\alpha-\mathrm{P}$ (see Fig. 1, male 2, standard 3). The third peak (C) comigrated with di-hydroxylated progestins (Fig. 1, males 1, 2 and 3 , see standard 5). Other minor radioactivity peaks occurred in the migrating zone of androgens such as 11KT, 11ß-hydroxyandrostenedione, adrenosterone and androstenedione (see standards number 4, 6, 7 and 10 respectively in Fig. 1, males 1, 2 and 3). However, androgens were not further investigated.
'A' TLC peak or ' $17,203,21-P$ zone'. The TLC 'A' peak was further analyzed by HPLC showing various minor radioactivity peaks not co-eluting with standards neither with 17,20ß,21-P nor with 11-20ßS (Fig. 1). However, the polar zone that could contain 17,20ß,21-P was further investigated. A second replicate of male 2 was analyzed by TLC and HPLC and the zone that theoretically should contain 17,20ß,21-P was analyzed after specific enzymatic oxidation of the 20 $\beta$-hydroxyl group by immunochemistry assays. The enzymatic treatment did not induce any change in the original radioactivity profiles observed before the treatment; 17,21-P would have been detected if 17,20ß,21-P had been present. Furthermore, the percentage of binding of TLC peak A to a high titre anti-17,20ß,21-P serum was significantly low $(1.5 \%)$.

'B' TLC peak or 'cortisol zone'. The 'B' peak which migrated with the same migration coefficient as the cortisol standard was especially evident in males 2 and 3 (Fig. 1). A further study by HPLC using different solvent systems (III and IV) has been made using cortisol as standard. HPLC analysis of this peak confirmed the occurrence of tritiated cortisol in two of the three males studied, using the solvent systems III and IV. Figure 2 represents the results obtained with system III. A similar profile was observed using system IV (data not shown). Besides, after acetylation of the peak purified by TLC and HPLC the percentage of recovery in the zone of TLC co-migrating with the acetylated true cortisol was $64 \%$ and $49 \%$ for males 2 and 3, respectively.

\section{Chromatograms after TLC analysis}

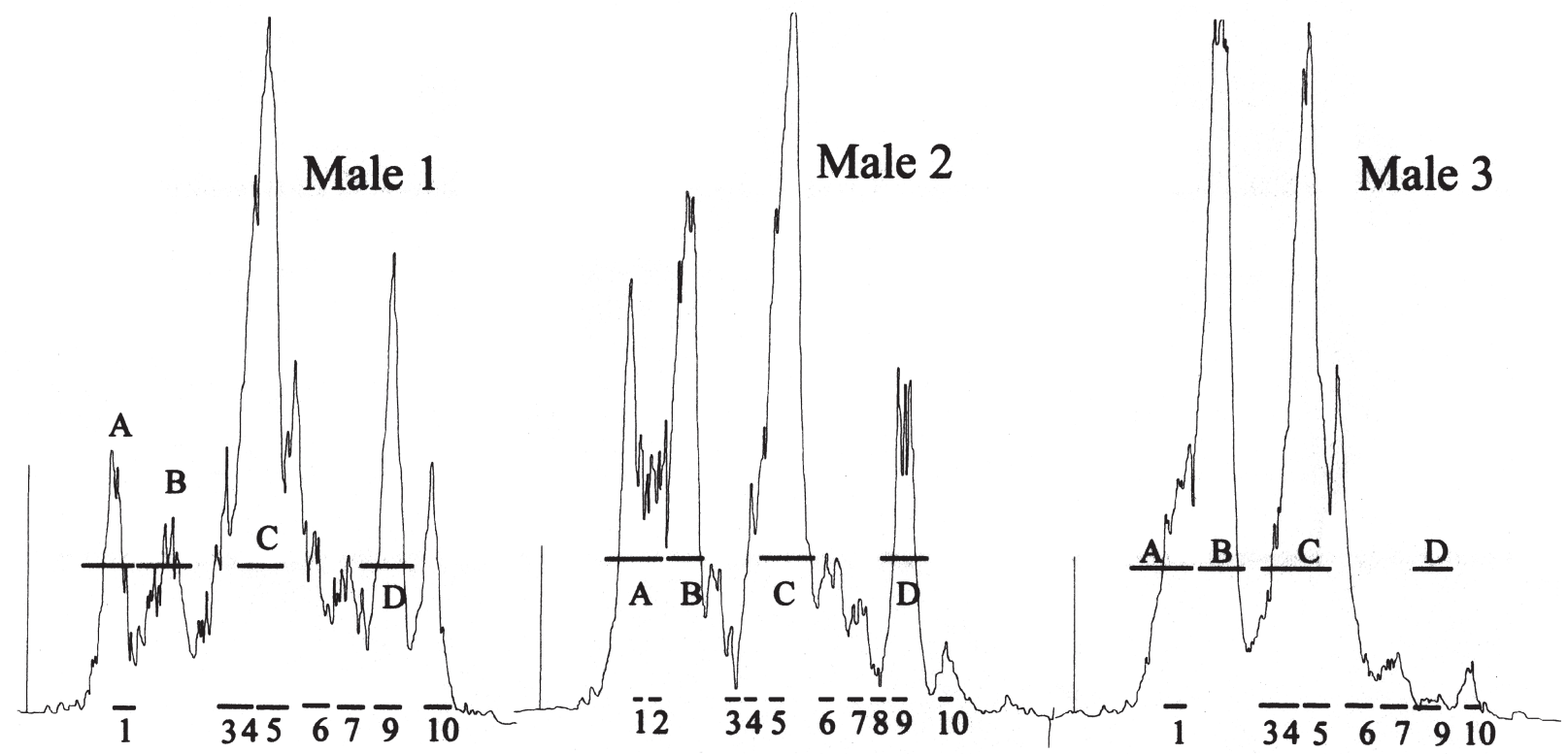

Fig. 1. Radiochromatogram after TLC analysis of spermiating testes of Micropogonias furnieri males 1, 2 and 3 after toluene/cyclohexane 50/50 v/v (system I) and benzene/acetone $80 / 20 \mathrm{v} / \mathrm{v}$ (system II). The TLC zones further analyzed by HPLC are shown as A, B and C. The peak of precursor is shown as D. The authentic standards used were: $1=$ 20 -dihydrocortisone; $2=17,20,21-\mathrm{P} ; 3=17,20 \alpha-\mathrm{P} ; 4=11 \mathrm{KT} ; 5=17,20 ß-\mathrm{P} ; 6=11 ß \mathrm{OH}-\mathrm{A} ; 7=\mathrm{Ad} ; 8=$ testosterone; $9=17-\mathrm{P} ; 10=\mathrm{A}$. 


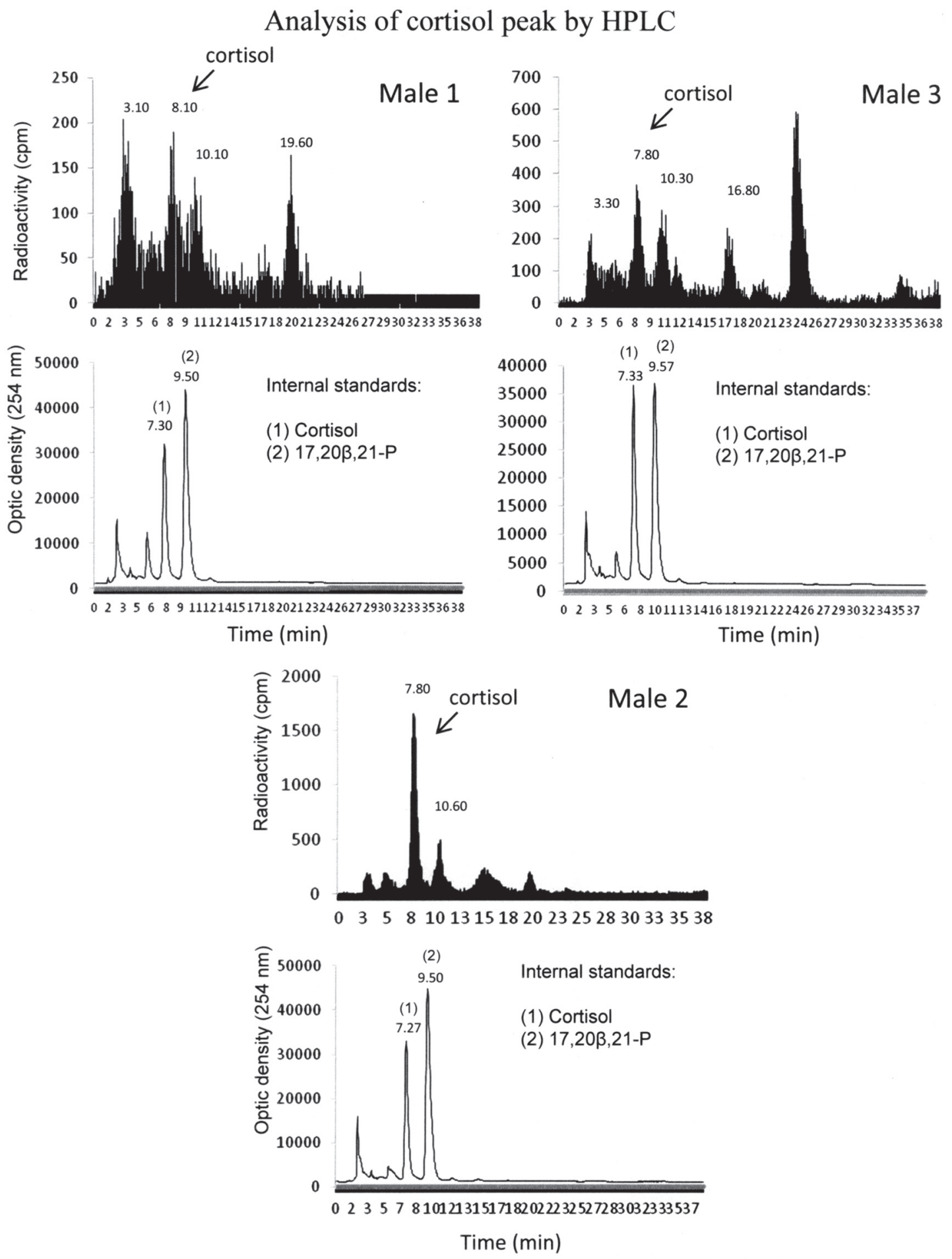

Fig. 2. Analysis of zone B of TLC or cortisol area (see Fig. 1) by HPLC using methanol/acetonitrile/water 33/26/41 v/v/v (system III) in Micropogonias furnieri.

'C' TLC peak or '17,20ß-P zone'. A large radioactivity peak was detected for the three investigated males. Further investigation of the ' $\mathrm{C}$ ' TLC peak by HPLC showed that the main metabolite co-eluted with 17,20ß-P after analysis with two different solvent systems (systems III and IV). Figure 3 shows the results obtained with system III. A similar profile was observed using system IV (data not shown). Furthermore, specific enzymatic oxidation of the 20ß-hydroxyl group of the suspected 17,20 $\beta$-P gave a radioactivity peak which co-eluted with a 17-P inert standard in HPLC (system III) (data not shown). This TLC area also showed a minor radioactivity peak coeluting with 17,21 $\beta-\mathrm{P}$, another derivative of tritiated 17-P (male 2, Fig. 3). 

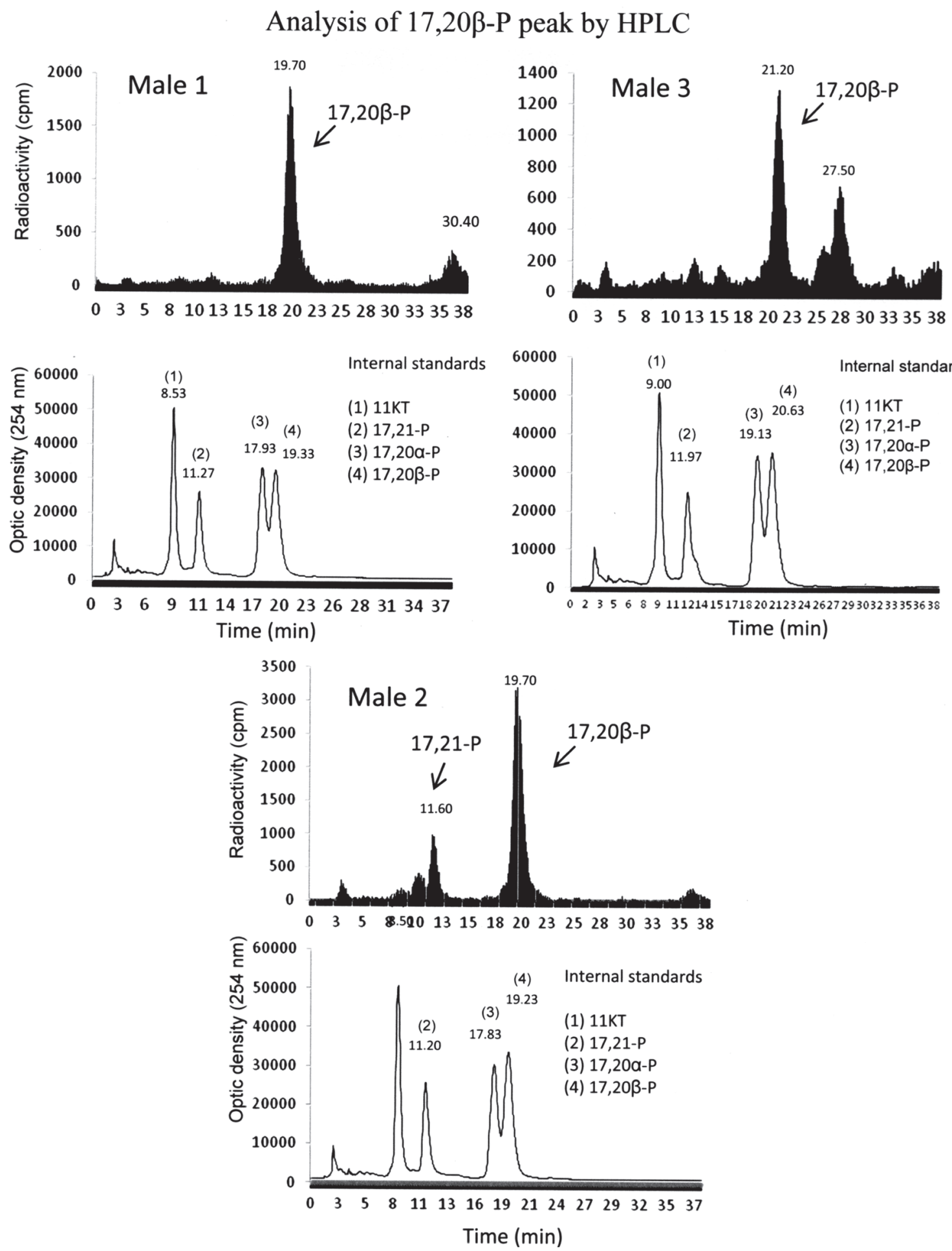

Fig. 3. Analysis of zone C of TLC or di-hydroxylated progestins area (see Fig. 1) by HPLC using methanol/acetonitrile/water 33/26/41 v/v/v (system III) in Micropogonias furnieri.

$17,20 \beta P$ circulating levels during the testicular cycle. $17,20 \beta-P$ was undetectable in the plasma of nine males caught at the immature phase (Stage 1) and first stages of spermatogenesis (Stage 2) (Fig. 4). 17,20ß-P increased clearly in blood when males were at whole spermatogenesis phases (Stage 3), with variable concentrations ranging from 76 to
$840 \mathrm{pg} \mathrm{mL}^{-1}$ with a mean value of $364 \pm 264 \mathrm{pg} \mathrm{mL}^{-1}$. Males releasing sperm (Stage 4) also showed a large variability in their 17,20ß-P circulating levels; $23 \%$ had undetectable levels and the other males showed levels ranging from 117 to $1047 \mathrm{pg} \mathrm{mL}^{-1}$ with a mean $\pm \mathrm{SD}$ value of $432 \pm 204 \mathrm{pg} \mathrm{mL}^{-1}$. One male at resting stage (stage 6) had $208 \mathrm{pg} \mathrm{mL}^{-1}$. 


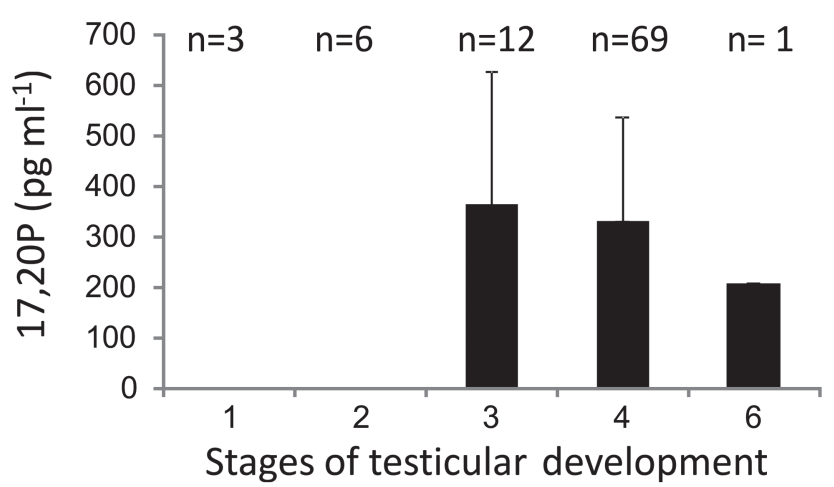

Fig. 4. Plasma level of 17,20ß-P in males at different stages of development sampled at the Río de la Plata estuary. 1: Immature testis; 2: Developing testis (early spermatogenesis); 3: Fully developed testis (whole spermatogenesis), 4: Spermiating testis; 6: Resting testis. $\mathrm{n}=$ number of fish collected for each stage.

\section{Discussion}

The results demonstrate that 17,20 $\beta-\mathrm{P}$ and cortisol are the main metabolites of $17 \mathrm{P}$ produced by Micropogonias furnieri spermiating testes. However, we expected the presence of 17,20 $3,21-\mathrm{P}$ as a major metabolite. In a close related species, M. undulatus, 17,20 $3,21-\mathrm{P}$ is the major progestin identified in the ovaries during final oocyte maturation after oocyte maturation (Trant et al., 1986). In males, treatments with 17,20 $3,21-\mathrm{P}$ resulted in an increased percentage of motile sperm and in sperm velocity (Thomas et al., 2004). This effect occurred via a progestin membrane receptor $\alpha(\mathrm{mPR} \alpha)$ (Thomas et al., 2005, 2007; Thomas, 2012) highly specific for 17,20ß,21-P (Thomas et al., 1997). However, there is no information validating the endogenous production of this steroid for $M$. undulatus. We could not identify $17,20,21-\mathrm{P}$ in $M$. furnieri testes during spermiation even if a high activity of 20ß-hydroxysteroid dehydrogenase (20ßHSD) and 21-hydroxylase, the two enzymes required for the synthesis of 17,20ß,21-P from the precursor (17P), were detected.

Changes in plasma levels during $M$. furnieri testicular cycle were studied in order to clarify the participation of $17,20 \beta-\mathrm{P}$ at an endocrine level. 17,20 $\beta$-P circulating levels in spermiating males were relatively low (0.1-1 ng $\mathrm{mL}^{-1}$ ) and $M$. furnieri can be considered one of the species with smaller amounts of 17,20 $\beta$-P. In fact, the amount of $17,20 \beta-\mathrm{P}$ in this species can be considered small compared to other teleost fish as salmonids (Scott et al., 2010). The important increase in 17,20 $3-\mathrm{P}$ levels in blood plasma during the whole spermatogenesis and spermiation stages compared to the undetectable levels at the first development stages sustain the idea that this progestin is involved in the regulation of these two stages of testicular development. It is interesting to note that the presence of 17,20 $\beta$-P has been considered essential at the beginning of the meiosis process in eels (Miura et al., 2006). This suggests that during the phase in which germ cells enter in meiosis some levels of 17,20 $\beta$-P are needed to sustain the process and could explain the relative high levels observed in $M$. furnieri during spermatogenesis.

At the final stage of $M$. furnieri testicular cycle 17,20 $\beta-P$ plasma levels behave differently than in total spawners as salmonids. An elevated peak of 17,20 $\beta$-P has been largely described in total spawners (Scott et al., 2010). This significant increase of $17,20 \beta-\mathrm{P}$ production and release to plasma can be explained by the important increase in the number of spermatozoa capable to produce large amounts of 17,20 $\beta$-P when the precursor is present (Ueda et al., 1984). Thus, the clear increase of this progestin during spermiation reflects the type of spermatogenesis of total spawners showing some degree of synchronization when germ cells mature in testes (Billard \& Escaffre, 1975) and containing almost exclusively spermatozoa in spermiant testis. Contrary to total spawners, serial spawners as $M$. furnieri do not have a high degree of synchronisation during spermatogenesis, and the spermatogenetic wall is present even during spermiation (Vizziano et al., 2002b). If $M$. furnieri germ cells, including spermatozoa, have the ability to convert precursors into 17,20 $\beta-\mathrm{P}$, as in salmonidae (Sakai et al., 1989; Vizziano et al., 1996), the dynamics of spermatogenesis could explain the absence of a clear peak of 17,20 $\beta$-P during spermiation in this sciaenid fish. Nevertheless, it must be reminded that not all fish have sperm with the capacity to convert 17-P into 17,20ß-P (Scott et al., 2010).

Another point needing further analyses is the high production of 17,20 $\beta$-P in testes in vitro during spermiation and not reflected in high amounts in plasma during the same phase. One explanation could be that $17,20 \beta-\mathrm{P}$ is intratesticularly produced and concentrated and is not released in high amounts to blood. This could be possible if $17,20 \beta-P$ play an autocrine or paracrine function in $M$. furnieri testes as it was demonstrated in other fish (Miura et al., 1992; Thomas et al., 2004; Milla et al., 2008; Tubbs et al., 2011). Another explanation regarding the small amounts of $17,20 \beta-\mathrm{P}$ is the possible conjugation and metabolism that may occur in peripheral tissues rapidly removing this steroid from blood (Scott et al., 2010).

The most surprising finding of this work was the cortisol production by spermiating testes since corticosteroids are primarily produced in interrenal glands (Fostier et al., 1983; Kime \& Scott, 1993; Lee et al., 2000). The cortisol synthesis by spermiant testes of the white croaker under the influence of the precursor 17P is sustained by the presence of the very active 21-hydroxylase, that converts $17 \mathrm{P}$ into $17,21 \mathrm{P}$. The latter can be converted into cortisol by the presence of an active $11 \beta$ hydroxylase. This pathway of cortisol biosynthesis in testes is coincident with the pathways proposed by Milla et al. (2009). In this revision the authors highlighted that the activity of 21-hydroxylase has not been previously shown in teleost fish testes. We are hereby providing evidence of a clear activity of 21-hydroxylase in teleost testes. 
The physiological effect of cortisol needs a binding to receptors. In fish it has been shown that cortisol transactivate in vitro the two glucocorticoid receptors (Bury et al., 2003). Interestingly, a mineralocorticoid-like receptor initially isolated from a testes cDNA library was described to have high affinity for cortisol (Colombe et al., 2000). The receptivity for the cortisol is present in fish testes but receptors by which they exert a physiological effect are not well understood.

The role of cortisol in the reproduction of male fish shows contradictory effects at different stages of the testicular development. Cortisol at low doses can affect the early spermatogenesis by stimulating the spermatogonial mitosis but can also inhibit the effect of 11-ketotestosterone on the spermatogonia proliferation when higher doses are used. Moreover, cortisol also induces retardation on spermatogenesis development probably via inhibition of androgens (Milla et al., 2009). It has been shown that later during the spermiation phase cortisol has a direct negative effect on the production of 17,20 $\beta$-P (the MIS in male trout) testicular production (Milla et al., 2008) suggesting that cortisol affects the late phases of male reproduction. The presence of both 17,20P and cortisol at the spermiation phase of the white croaker do not sustain the idea of a negative effect of the testicular cortisol on $17,20 \mathrm{P}$ in this species. Recently, it has been proposed that another corticosteroid, 11-deoxycorticosterone (DOC), and the mechanisms of action of 17,20 $-\mathrm{P}$ are linked during the spermiation stage, in order to control milt fluidity (Milla et al., 2008). The cortisol, being the second major metabolite detected in males testes during spermiation could be a regulator of testes hydration as it was proposed in trout for other corticosteroids.

The results obtained suggest that $17,20 \beta-\mathrm{P}$ is a good candidate to be considered as steroid mediator of spermatogenesis and sperm maturation and release in $M$. furnieri. The action of cortisol during testicular development needs further studies.

\section{Acknowledgments}

Funding was provided by the International Foundation for Science (Sweden, Grant A/2340-1, A/2340-2) and by the Institut National de la Recherche Agronomique (INRA, Rennes, France). The first author received a fellowship from the Comisión Sectorial de Investigación Científica (CSIC) from the Universidad de la República (Montevideo, Uruguay). Dr. Alexander Scott (MAFF, Lowestoff, Suffolk, U.K.) generously donated anti-20ßS serum.

\section{References}

Acha, E. M., H. Mianzan, C. A. Lasta \& R. A. Guerrero. 1999. Estuarine spawning of the whitemouth croaker Micropogonias furnieri (Pisces: Sciaenidae), in the Río de la Plata, Argentina. Marine \& Freshwater Research, 50: 57-65.
Baynes, S. M. \& A. P. Scott. 1985. Seasonal variations in parameters of milt production and in plasma concentration of sex steroids of male rainbow trout (Salmo gairdneri). General and Comparative Endocrinology, 57: 150-160.

Billard, R. \& A. -M. Escaffre. 1975. Identification des stades de la spermatogenese de la truite Fario d'apres la morphologie des gonades et la spermiation. Bulletin Français de Pisciculture, 256: 111-116.

Bury, N. R., A. Sturm, P. Le Rouzic, C. Lethimonier, B. Ducouret, Y. Guiguen, M. Robinson-Rechavi, V. Laudet, M. E. RafestinOblin \& P. Prunet. 2003. Evidence for two distinct functional glucocorticoid receptors in teleost fish. Journal of Molecular Endocrinology, 31: 141-156.

Chen, S. X., F. F. L. Almeida, E. Andersson, G. L. Taranger, R. Schmidt, R. W. Schulz \& J. Bogerd. 2012. Cloning, pharmacological characterization and expression analysis of Atlantic cod (Gadus morhua, L.) nuclear progesterone receptor. General and Comparative Endocrinology, 179: 71-77.

Chen, S. X., J. Bogerd, N. E. Schoonen, J. Martijn, P. P. de Waal \& R. W. Schulz. 2013. A progestin (17,20 $\boldsymbol{\beta}$-dihydroxy-4pregnen-3-one) stimulates early stages of spermatogenesis in zebrafish. General and Comparative Endocrinology, 185: $1-9$.

Colombe, L., A. Fostier, N. Bury, F. Pakdel \& Y. Guiguen. 2000. A mineralocorticoid-like receptor in the rainbow trout, Oncorhynchus mykiss: cloning and characterization of its steroid binding domain. Steroids, 65: 319-328.

Cousseau, M. B., C. P. Cotrina, H. D. Cordo \& G. E. Burgos. 1986. Análisis de datos biológicos de la corvina rubia (Micropogonias furnieri) y pescadilla de red (Cynoscion striatus) obtenidos en dos campañas del año 1983. Publicación de la Comisión Técnica Mixta Argentino-Uruguaya, 1: 319-332.

Dépêche, J. \& O. Sire. 1982. In vitro metabolism of progesterone and $17 \alpha$-hydroxyprogesterone in the testis of the rainbow trout, Salmo gairdneri Rich., at different stages of spermatogenesis. Reproduction Nutrition Développement, 22: 427-438.

Fostier, A., B. Jalabert, R. Billard, B. Breton \& Y. Zohar. 1983. The gonadal steroids. Pp. 277-372. In: Hoar, W. S., D. J. Randall \& E. M. Donaldson (Eds.). Fish physiology. New York, Academic Press. v. 9: Reproduction. Part A: Endocrine tissues and hormones.

Fostier, A., B. Jalabert, C. Campbell, M. Terqui \& B. Breton. 1981. Cinétique de la libération in vitro de la $17 \alpha-20 \beta-$ dihydroprogestérone par des follicules de truite arc-enciel, Salmo gairdnerii. Comptes Rendus de l'Académie de Sciences de Paris, 292: 777-780

Fostier, A., B. Jalabert \& M. Terqui. 1973. Physiologie-Action prédominant d'um dérivé hydroxylé de la progestérone sur la maturation in vitro des ovocytes de la truite arc-en-ciel, Salmo gairdnerii. Comptes Rendus de l'Académie de Sciences de Paris, série D, 277: 421-424.

Fostier, A., F. Le Gac \& M. Loir. 1987. Steroids in male reproduction. Pp. 239-245. In: Idler, D. R., L. W. Crim \& J. M. Walsh (Eds.). Proceedings of the Third International Symposium on Reproductive Physiology of Fish. St. John's, Nfld, Canada, Marine Science Research Laboratory.

García-Alonso, J., A. Nappa, A. Rey, G. Somoza, A. Rey \& D. Vizziano. 2004. Steroid metabolism in vitro during final oocyte maturation in white croaker Micropogonias furnieri (Pisces: Sciaenidae). Brazilian Journal of Biology, 64: 211-220. 
Gomez, J. M., C. Weil, M. Ollitrault, P. -Y. Le Bail, B. Breton \& F. Le Gac. 1999. Growth Hormone (GH) and Gonadotropin Subunit Gene Expression and Pituitary and Plasma Changes during Spermatogenesis and Oogenesis in Rainbow Trout (Oncorhynchus mykiss). General and Comparative Endocrinology, 113: 413-428.

Hanna, R. N. \& Y. Zhu. 2009. Expression of membrane progestin receptors in zebrafish (Danio rerio) oocytes, testis and pituitary. General and Comparative Endocrinology, 161: 153-157

Khan, M. N., P. K. Reddy, R. L. Renaud \& J. F. Leatherland. 1997. Application of HPLC methods to identify plasma profiles of 11-oxygenated androgens and other steroids in arctic charr (Salvelinus alpinus) during gonadal recrudescence. Comparative Biochemistry and Physiology, 118C: 221-227.

Kime, D. E. 1995. Steroid nomenclature. General and Comparative Endocrinology, 98: 119-120.

Kime, D. E. \& A. P. Scott. 1993. In vitro synthesis of $20 \alpha$-reduced and of 11- and 21-oxygenated steroids and their sulfates by testes of the goldfish (Carassius auratus): testicular synthesis of corticosteroids. Fish Physiology and Biochemistry, 11: 287-292.

Kusakabe, M., I. Nakamura, J. Evans, P. Swanson \& G. Young. 2006. Changes in mRNAs encoding steroidogenic acute regulatory protein, steroidogenic enzymes and receptors for gonadotropins during spermatogenesis in rainbow trout testes. Journal of Endocrinology, 189: 541-554.

Lee, S. T. L., T. J. Lam \& C. H. Tan. 2000. Corticosteroid biosynthesis in vitro by testes of the grouper (Epinephelus coioides) after $17 \alpha$-methyltestosterone-induced sex inversion. Journal of Experimental Zoology, 287: 453-457.

Le Gac, F. \& M. Loir. 1988. Control of testis function in fish: in vitro studies of gonadotropic regulation in the trout (Salmo gairdneri). Reproduction Nutrition Développement, 28: 1031-1046.

Macchi, G. J., E. M. Acha \& M. I. Militelli. 2003. Seasonal egg production of whitemouth croaker (Micropogonias furnieri) in the Río de la Plata estuary, Argentina-Uruguay. Fisheries Bulletin, 101: 332-342.

Mathews, S., I. A. Khan \& P. Thomas. 2002. Effects of the maturation-inducing steroid on LH secretion and the GnRH system at different stages of the gonadal cycle in Atlantic croaker. General and Comparative Endocrinology, 126: 287-297.

Milla, S., X. Terrien, A. Sturm, F. Ibrahim, F. Giton, J. Fiet, P. Prunet \& F. Le Gac. 2008. Plasma 11-deoxycorticosterone (DOC) and mineralocorticoid receptor testicular expression during rainbow trout Oncorhynchus mykiss spermiation: implication with 17alpha, 20beta-dihydroxyprogesterone on the milt fluidity. Reproductive Biology and Endocrinology, 6: 19.

Milla, S., N. Wang, S. N. M. Mandiki \& P. Kestemont. 2009. Corticosteroids: Friends or foes of teleost fish reproduction? Comparative Biochemistry and Physiology, Part A 153: 242251.

Miura, T., M. Higuchi, Y. Ozak, T. Ohta \& C. Miura. 2006. Progestin is an essential factor for the initiation of the meiosis in spermatogenetic cells of the eel. Proceedings of the Natural Academy of Sciences, 103: 7333-7338.

Miura, T. \& C. I. Miura. 2003. Molecular control mechanism of fish spermatogenesis. Fish Physiology and Biochemistry, 28: 181-186.
Miura, T., K. Yamauchi, H. Takahashi \& Y. Nagahama. 1992. The role of hormones in the acquisition of sperm motility in salmonid fish. The Journal of Experimental Zoology, 261: 359-363.

Mugnier, C. 1996. Analyse morphologique et endocrinienne des dernières étapes de l'ovogenèse et recherche d'un traitement de l'induction de l'ovulation chez le turbot (Scophthalmus maximus L.). Unpublished Ph.D. Dissertation. Université de Rennes I. Rennes, France, 100p.

Nagahama, Y. 1987. 17 $\alpha$, 20 $\beta$-dihydroxy-4-pregnen-3-one: a teleost maturation-inducing hormone. Development, Growth \& Differentiation, 29: 1-12.

Nagahama, Y. \& M. Yamashita. 2008. Regulation of oocyte maturation in fish. Development, Growth \& Differentiation, 50: S195-S219.

Planas, J. V. \& P. Swanson. 1995. Maturation-associated changes in the response of the salmon testis to the steroidogenic actions of gonadotropins (GTH I and GTH II) in vitro. Biology of Reproduction, 52: 697-704.

Planas, J. V., P. Swanson \& W. W. Dickhoff. 1993. Regulation of testicular steroid production in vitro by gonadotropins (GTH I and GTH II) and cyclic AMP in coho salmon (Oncorhynchus kisutch). General and Comparative Endocrinology, 91: 8-24.

Sakai, N., H. Ueda, N. Suzuki \& Y. Nagahama. 1989. Involvement of sperm in the production of $17 \alpha, 20 \beta$-dihydroxy-4pregnen-3-one in the testis of spermiating rainbow trout, Salmo gairdneri. Biomedical Research, 10: 131-138.

Schulz, R. W., M. Andriske, P. J. Lembke \& V. Blüm. 1992. Effect of salmon gonadotropic hormone on sex steroids in male rainbow trout: plasma levels and testicular secretion in vitro. Journal of Comparative Physiology B, 162: 224-230.

Schulz, R. \& V. Blüm. 1990. Steroid secretion of rainbow trout testis in vitro: variation during the reproductive cycle. General and Comparative Endocrinology, 80: 189-198.

Schulz, R. W., L. R. de França, J. -J. Lareyre, F. Le Gac, H. Chiarini-Garcia, R. H. Nobrega \& T. Miura. 2010. Spermatogenesis in fish. General and Comparative Endocrinology, 165: 390-411.

Scott, A. P. \& A. V. M. Canario. 1987. Status of oocyte maturation-inducing steroids in teleosts. Pp. 224-234. In: Idler, D. R., L. W. Crim \& J. M. Walsh. (Eds.). Proceedings of the Third International Symposium on Reproductive Physiology of Fish. St. John's, Nfld, Canada, Marine Science Research Laboratory.

Scott, A. P. \& P. W. Sorensen. 1994. Time course of release of pheromonally active gonadal steroids and their conjugates by ovulatory goldfish. General and Comparative Endocrinology, 96: 309-323.

Scott, A. P. \& J. P. Sumpter. 1989. Seasonal variations in testicular germ cell stages and in plasma concentrations of sex steroids in male rainbow trout (Salmo gairdneri) maturing at 2 years old. General and Comparative Endocrinology, 73: 46-58.

Scott, A. P., J. P. Sumpter \& N. Stacey. 2010. The role of the maturation-inducing steroid, 17,20 $\beta$-dihydroxypregn-4-en3-one, in male fishes: a review. Journal of Fish Biology, 76: 183-224.

Thomas, P. 1994. Hormonal control of final oocyte maturation in sciaenid fishes. Pp. 619-625. In: Davey, K. G., R. E. Peter \& S. $\mathrm{S}$. Tobe (Eds.). Perspectives in comparative Endocrinology. Ottawa, National Research Council of Canada. 
Thomas, P. 2012. Rapid steroid hormone actions initiated at the cell surface and the receptors that mediate them with an emphasis on recent progress in fish models. General and Comparative Endocrinology, 175: 367-383.

Thomas, P., D. Breckenridge-Miller \& C. Detweiler. 1997. Binding characteristics and regulation of the 17,203,21trihydroxy-4-pregnen-3-one (20 $\beta-S)$ receptor on testicular and sperm plasma membranes of spotted seatrout (Cynoscion nebulosus). Fish Physiology and Biochemistry, 17: 109-116.

Thomas, P., Y. Pang, J. Dong, P. Groenen, J. Kelder, J. de Vlieg, Y. Zhu \& C. Tubbs. 2007. Steroid and G protein binding characteristics of the seatrout and human progestin membrane receptor $\alpha$ subtypes and their evolutionary origins. Endocrinology, 148: 705-718.

Thomas, P., Y. Pang, Y. Zhu, C. Detweiler \& K. Doughty. 2004. Multiple rapid progestin actions and progestin membrane receptor subtypes in fish. Steroids, 69: 567-573.

Thomas, P., C. Tubbs, C. Detweiler, S. Das, L. Ford \& D. Breckenridge-Miller. 2005. Binding characteristics, hormonal regulation and identity of the sperm membrane progestin receptor in Atlantic croaker. Steroids, 70: 427-433.

Trant, J. M., P. Thomas \& C. H. L. Shackleton. 1986. Identification of $17 \alpha, 20 \beta, 21$-Trihydroxy-4-pregnene-3one as the major ovarian steroid produced by the teleost Micropogonias undulatus during final oocyte maturation. Steroids, 47: 89-99.

Tubbs, C., M. Pace \& P. Thomas. 2010. Expression and gonadotropin regulation of membrane progestin receptor alpha in Atlantic croaker (Micropogonias undulatus) gonads: role in gamete maturation. General and Comparative Endocrinology, 165: 144-154.

Tubbs, C., W. Tan, B. Shi \& P. Thomas. 2011. Identification of

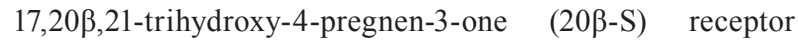
binding and membrane progestin receptor alpha on southern flounder sperm (Paralichthys lethostigma) and their likely role in $20 \beta-\mathrm{S}$ stimulation of sperm hypermotility. General and Comparative Endocrinology, 170: 629-639.

Tubbs, C. \& P. Thomas. 2008. Functional characteristics of membrane progestin receptor alpha (mPRalpha) subtypes: a review with new data showing mPRalpha expression in seatrout sperm and its association with sperm motility. Steroids, 73: 935-941.

Ueda, H., A. Kambegawa \& Y. Nagahama. 1984. In vitro 11ketotestosterone and 17 $2,20 \beta$-dihydroxy-4-pregnen-3-one production by testicular fragments and isolated sperm of rainbow trout, Salmo gairdneri. The Journal of Experimental Zoology, 231: 435-439.
Ueda, H., A. Kambegawa \& Y. Nagahama. 1985. Involvement of gonadotrophin and steroid hormones in spermiation in the amago salmon, Oncorhynchus rhodurus, and goldfish, Carassius auratus. General and Comparative Endocrinology, 59: 24-30.

Vizziano, D., F. Forni, G. Saona \& W. Norbis. 2002b. Reproduction of Micropogonias furnieri in a shallow temperate coastal lagoon in the Southern Atlantic. Journal of Fish Biology, 61(Supplement A): 196-206.

Vizziano, D., A. Fostier, F. Le Gac \& M. Loir. 1996. 20ß-hydroxysteroid dehydrogenase activity in nonflagellated germ cells of rainbow trout testis. Biology of Reproduction, 54: 1-7.

Vizziano, D., A. Fostier, M. Loir \& F. Le Gac. 2008. Testis development, its hormonal regulation and spermiation induction in teleost fish. Pp. 103-140. In: Alavi, S. M. H., J. J. Cosson, K. Coward \& G. Rafiee. (Eds.). Fish Spermatology. Oxford, Alpha Science International.

Vizziano, D. \& F. Le Gac. 1998. Effect of gonadotropin type II and 17-hydroxy-4-pregnene-3,20-dione on 17,20 $\beta$-dihydroxy-4pregnen-3-one production by rainbow trout testes at different developmental stages. Fish Physiology and Biochemistry, 19: 269-277.

Vizziano, D., F. Le Gac \& A. Fostier. 1995. Synthesis and regulation of $17 \alpha$-hydroxy-20ß-dihydroprogesterone in immature males of Oncorhynchus mykiss. Fish Physiology and Biochemistry, 14: 289-299.

Vizziano, D., P. Puig, C. Mesones \& G. J. Nagy. (Eds.). 2002a. The Río de la Plata. Research for the Management of the Environment, the Fish Resources and Fishery in the Saline Front. Montevideo: ECOPLATA-UNESCO.

Yueh, W. S. \& C. F. Chang. 1997. 17 $\alpha, 20 \beta, 21$-trihydroxy4-pregnen-3-one and 17, $20 \beta$-dihydroxy-4-pregnen-3one stimulated spermiation in protandrous black porgy, Acanthopagrus schlegeli. Fish Physiology and Biochemistry, 17: 187-193.
Submitted January 04, 2015

Accepted May 27, 2015 by Bernardo Baldisserotto Published September 25, 2015 
